\title{
The Challenges of the IS/IT Projects in the Healthcare Sector
}

Jorge Gomes, Universidade Lusófona de Humanidades e Tecnologias, Lisboa, Portugal

Mário Romão, ISEG, Universidade De Lisboa, Lisboa, Portugal

\begin{abstract}
Essentially, the purpose of investment in information systems and information technology (IS/IT) is to improve the operational efficiency of the organizations, reducing costs and improving levels of quality. Thus, many traditional appraisal techniques are used to evaluate tangible benefits, which are based on direct project costs. Since the 1980s, IS/IT has positioned itself as a strategic tool that through flexibility and innovative ways can produce superior performance. The health sector has sought to improve its effectiveness and efficiency by adopting IS/IT solutions to increase the quality of services, namely patient safety, organizational efficiency, and end-user satisfaction. Hospitals are complex organizations, and this complexity magnifies the opportunity for inevitable human errors. A poorly integrated system can decrease operational efficiency and reduce the quality of healthcare services. The issue remains controversial, as evidenced by several articles. The authors noticed that emergent technologies may offer opportunities to those who can exploit them effectively.
\end{abstract}

\section{KEYWORDS}

IS/IT Implementations in Healthcare, IS/IT in Healthcare, IS/IT Investments in Healthcare, IS/IT Projects in Healthcare, Success of IS/IT in Healthcare

\section{INTRODUCTION}

The business value of Information Systems and Information Technology (IS/IT) investments is predicted to remain, one of the major topics for the researchers (Dehning et al., 2014; Roztocki \& Weistroffer, 2008). Some early studies (Dos Santos et al., 1993; Hitt \& Brinjolfsson, 1996; Im et al., 2001; Rai et al., 1997; West \& Courtney, 1993) doubt from the economic value of IS/IT, the vast majority of authors find empirical evidence and theoretical arguments in favor of both the operational and strategic relevance of IS/IT (Aral et al., 2007; Beccalli, 2007; Dedrick et al., 2003; Dehning et al., 2003; Han et al., 2011; Kim et al., 2009; Kohli \& Grover, 2008; Lee et al., 2011; Lin et al., 2006; Mahmood \& Mann, 2005; Neirotti \& Paolucci, 2007; Peslak, 2003; Ramirez et al., 2010; Santhanam \& Hartono, 2003; Shin, 2006; Swierczek \& Shrestha, 2003; Zhang, 2005). As competition increases because of globalization and other market factors, it is even more important that an organization performs at its best capabilities. Organizations are being put under increasing pressure to justify the large amount of financial resources spent on IS/IT assets (Gomes et al., 2013). The decision-making process over IS/IT investments is not 
as objective and transparent as it is claimed to be, creating significant failures on achievement of the objectives and their related benefits (Berghout et al., 2005). Organizations seek benefits and value only in monetary terms, which have resulted in a lot of wasted energy, time and money. It is very common that organizations place their focus on the technical aspects such as does it work? rather than the social aspects such as is this adopted successfully? or from a business perspective is this delivering value? (Gomes \& Romão, 2017). The health care sector has a unique, complex, dynamic context which differ significantly from other industries in which IS/IT have been applied (Chau \& Hu, 2002; Westbrook et al., 2004). IS/IT for healthcare have been referred as a key instrument that facilitate communication, processing and transmission of information by electronic means, with the aim of improving human health (Bukachi \& Pakenham-Walsh, 2007; Drury, 2005; Häyrinen et al., 2008). The difficulties due to the implementation of IS/IT solutions and assessment of their performance have been acknowledged by several scholars (Lueg \& Lu, 2012, 2013). Therefore, finding means to overcome these issues and to improve the performance and return from investments in IS/IT has been a research focus of the last decades. Grounded by theory of competitive strategy, several authors argued that IS/IT can contribute to more profits if it cannot be replicated easily or it can make product differentiation (Mithas et al., 2012). Although many studies have focused on the consequences of IS/IT investments, fewer studies have examined factors that impact the IS/IT capabilities (Devaraj \& Kohli, 2003; Brynjolfsson, 1993). IS/IT investments are now spread worldwide, adopted and used in many sectors, including the health sector. While promoting population health has been the classic goal of public health practice and policy (Dawson \& Verweij, 2007), in recent decades, new objectives in terms of autonomy and equality have been introduced (Munthe, 2008). According to the World Health Organization, the use of IS/IT in health is not merely about technology but is a means to reach a series of desired outcomes across the entire health system (WHO, 2005). As stated by the European Community, the aim of IS/IT for Health is to improve significantly the quality, access and efficacy of healthcare for all citizens (EC, 2006). The move toward computer information systems began from the 1970s that ultimate goal of these systems is access to Electronic Health Record (EHR) (Shortliffe \& Barnett, 2014). EHR implementation results in the improved quality of care, cost effectiveness, customer-orientation and timely access to complete and precise information (Gagnon et al., 2014). Despite the potential benefits of EHR, its implementation is a difficult and complex task whose success and productivity depends on many factors (Yusof et al., 2008; Terry et al., 2008).

\section{METHODOLOGY}

This study is aimed to research the pattern of IS/IT projects in healthcare, using articles published in academic health management journals. Two stages were performed to achieve this objective. Firstly, the selection of academic documentation, and secondly the content analysis. The first step was performed through the collection of manuscripts based on a literature review using the article keywords in several academic databases. The titles, abstracts, keywords, and texts of these journals were searched based on the following the terms; IS/IT in Healthcare, Success of IS/IT in Healthcare, IS/IT Projects in Healthcare IS/IT investments in Healthcare, IS/IT Implementations in Healthcare. The goal was to identify as many applications of the IS/IT in the health sector. The second phase were the selection of documents that meet the study goals by comparing the documents retrieved with the objectives of our study.

\section{LITERATURE REVIEW}

\section{IS/IT Implementations}

According to several studies, there is a growing use of information and communication technologies by citizens and their families regarding the search for health information (Andreassen et al., 2007). 
Since the 1990's, the health sector has sought to improve its effectiveness and efficiency by adopting IS/IT to increase the levels of services quality, namely, patient safety, organizational efficiency and patient satisfaction (Bates \& Gawande, 2002; Pan et al., 2005; Raghupathi \& Tan, 1999). IS/IT in healthcare represents the integrated effort to collect, process, report and use health information and knowledge to influence policy-making, program action and research and further states that they are essential to the effective functioning of health systems worldwide (WHO, 2006). The broader meaning of this system refers to any system that captures, stores, manages or transmits information related to the health of individuals or the activities of organizations that work within the health sector (Bukachi \& Pakenham-Walsh, 2007; Mäenpää et al., 2009; Low \& Chen, 2012). The use of IS/IT in health provides an important support for specialized services, and increases the efficiency, quality, safety and also reduces medical errors (Low \& Chen, 2012). Hospitals are complex organizations and this complexity magnifies the opportunity for inevitable human errors (Weick \& Sutcliffe, 2001). A poorly integrated IS/IT can increase the frequency of medical errors, decrease operational efficiency, and reduce the quality of healthcare services (Themistocleous et al., 2009). Despite remarkable technical progress, failures have still been reported when integrating technically sound systems into processes of care (Lorenzi \& Riley, 2003). We live in times where healthcare providers generate significant amounts of personal data about patients and the major obstacle to the management of this increasing volume of information is the difficulty, or inability, of sharing information across systems and between organizations (Grimson et al., 2000). The greatest evolution in the role of information in the health system, namely on the doctor-patient relationship, is related to the enormous flow of medical or health information that is present on the Internet (Katz \& Rice, 2002); Netlleton et al., 2011; Murray et al., 2003). In this new reality patients play a more active role in their own healthcare (Collste, 2002). Medical information needed for clinical decision making has increased significantly, however the accessibility of health data is still poor, resulting in inappropriate decisions and sometimes in medical errors (Tierney, 2001). The IS/IT tools have been developed to increase the accessibility and management of medical information with the aim of supporting medical decision, of increasing the coordination between different healthcare providers, and of promoting the use of guidelines, thereby improving the global quality of care (Demiris \& Kneale, 2015). However, in addition to providing new capabilities, new technologies also impact the technical, social, organizational, economic, cultural, and political dimensions of work in new and different ways (Anderson \& Aydin, 1994). IS/ IT processes have the potential to significantly reduce the rate of these medical errors by providing relevant information in real time to all who need it (Bates et al., 2001; Chaudhry et al., 2006). An important challenge for the future is to seek for a real clinical integration of systems. Clinical integration between providers and hospitals has historically been a goal which is continually sought, but rarely achieved. It will become crucial that the design of future applications be integrated easier into existing systems, through open communication interface (Geissbuhler et al., 2001). There is a growing consensus that organizational factors are far more critical for the successful implementation of IS/IT, than technical considerations (Gomes \& Romão, 2016; Markus, 2000). Achieving successful change is much easier if all stakeholders are committed, and the earlier this commitment is achieved, the smoother is the path to a successful outcome (Bradley, 2006).

The use of IS/IT is recognized as being a major factor for the promotion of clinical practices and supportive care (Anderson, 1997; Kumar \& Preetha, 2012) and it is usually widespread in any modern hospital as a key instrument in healthcare delivery and in public healthcare (Drury, 2005; Lymberis \& Dittmar, 2007). The globally accepted assumption is that IS/IT can, and does have a positive effect on healthcare, although the evidence supporting its practical use is low (Wootton, 2009). In fact, many decisions on the implementation of the IS/IT in healthcare are made with little or no information about the impact and consequences of its use (Kazanjian \& Green, 2002). Information systems are used extensively in healthcare organizations to support various conventional data processing tasks. Range from simple systems, such as transaction processing systems, to complex systems, such as clinical decision support systems (Gomes, 2018). 


\section{IS/IT Project Failures}

We have been witnessing an increased boom in IS/IT healthcare investments and this phenomenon has expanded dramatically over last 10 years. The total investments for each large hospital are huge, yet the overall benefits and costs of hospital information systems have rarely been assessed (Byrne et al., 2010). When systems are evaluated, about $75 \%$ are considered to have failed (Heeks, 2002) and there is no evidence that they improve the productivity of health professionals (Smith et al., 2009). Along with the computerization of healthcare sector (Brailer \& Terasawa, 2003; Dick et al., 1997; Yasnoff et al., 2004; Barrett et al., 2003) systems failures have also been reported (Southon et al., 1999; Goddard, 2000; Poon et al., 2004) showing the enormous spending of money and loss of confidence in IS/IT from the side of users and managers.

The investments on IS/IT for healthcare are financially relevant and still growing worldwide. While the potential and benefits from the use of technological innovation in health are large, the risks are also substantial. Therefore, it seems wise that the organizations should give more attention to adopting formal project evaluations and benefits management methodologies to ensure that the expected benefits from investments are eventually realized (Dibb, 2001; Ward at el., 1996; Heeks \& Davies, 1999).

The results of the implementation of IS/IT projects in healthcare have revealed a waste of financial resources in acquiring large sized systems, which are totally ineffective. There is a widespread feeling that a significant proportion of initiatives in IS/IT healthcare have failed. Studies have identified high failure rates in IS/IT projects in various sectors, particularly in hospitals (Heeks \& Davies, 1999; Kaplan \& Harris-Salamone, 2009; Sumner, 1999; Wears \& Berg, 2005). A study by Gheorghiu (Gheorghiu, 2006) found that $70 \%$ to $80 \%$ of all IS/IT implementations fail. Heeks (Heeks, 2008) states that $35 \%$ of IS/IT projects are total failures and $50 \%$ partial failures, with only $15 \%$ being considered successful. Similarly, Kaplan and Harris-Salamone (Kaplan \& Harris-Salamone, 2009) confirmed a value greater than $30 \%$ for the failure rates of major health information technology projects.

Why do IS/IT systems implementations fail in health organizations? Healthcare projects are a complex undertaking, which depends largely on the quality of existing information (Bose, 2003). Organizations need to have three types of skills to produce successful projects (Lorenzi \& Riley, 2003): (a) Technical skills - which include a broad range of skills, such as the technical knowledge, experience, and abilities; (b) Project management skills - which include the knowledge, techniques, and skills necessary to manage successfully the IS/IT projects; (c) People and organizational skills - which include the wide range of skills necessary to effectively interface with all of the IS/IT stakeholders.

Several reasons are pointed out to project failures in healthcare, namely: (a) Lack of senior management commitment being incomplete or missing altogether (Bukachi \& Pakenham-Walsh, 2007); (b) Difficulties in the engagement of health professionals, and a lack of focus on end-users (Elder \& Clarke, 2007); (c) Incorrect specification requirements(Lucas, 2008; Gauld, 2007); (d) An absent or inadequate process of change (Yeo, 2002); (e) Poor knowledge of the complexity of health systems(Al-Ahmad et al., 2009); (f) Missing investments in human resources (Elder \& Clarke, 2007; Bukachi \& Pakenham-Walsh, 2007).

In various aspects, IS/IT implementations in healthcare are different from other projects from other industries. The key main differences were related to the environment, the diversity of systems and the devices that need to work, together with the challenge of integration and interoperability which is required to meet the expectations of different stakeholder groups regarding that which constitutes project success (Abouzhara, 2011).

\section{The Success of IS/IT Healthcare Projects}

IS/IT implementations are part of the continuous improvement cycle of healthcare quality and are based on several key success factors: Reliable information, engagement of all stakeholders in all phases of the work improvement and a proper infrastructure involving multidisciplinary teams (Brandrud et al., 2011). 
Success in the strategic use of IS/IT project success in healthcare relies on the integration of all systems, such as patient records, clinical decision support, transaction processing, digital imaging, and information reporting (Jensen, 2013). When diverse information systems are interoperable on a standardized platform, all stakeholders can streamline the implementation process, and improve the system quality (Grossmann et al., 2014). IS/IT project success also refers to user satisfaction, system use, perceived usefulness and system quality (Sabherwal et al., 2006).

The difficulties of implementing IS/IT projects in health, as well as the evaluation of their performance, have been the target of several researches in the last decades (Gomes, 2018; Lueg \& Lu, 2012; Santos et., 2014; Kaplan \& Harris-Salamone, 2009). Most of these researches focus on identifying critical factors or best practices that allow organizations to successfully complete their projects (Santos et al., 2014; Hung et al., 2014; Ghazvini \& Shukur, 2013). A comprehensive literature review on large-scale IS/IT projects executed in ten different countries identified eighteen frequently cited critical success factors (CSFs) for inter-enterprise systems implementations (Koumaditis et al., 2013). Five of them are the same as identified by the above-mentioned healthcare IS/IT implementations, namely: (a) Top management support; (b) Information systems adjustments; (c) Business process adjustments; (d) Organizational resistance; (e) Capability of key team members. Top management support has been argued to be the most critical factor for IS/IT project success (Nagi et al., 2008; Iacovou \& Nakatsu, 2008). Extant research largely focuses on the consequences of management support for IS/ IT projects (Liu et al., 2010; Dong et al., 2009; Liang et al., 2007).

Must has been written regarding the development of IS/IT initiatives in healthcare sector. The publications emphasized two main aspects: The slowness of adoption of these initiatives and the resistance to change (Lorenzi \& Riley, 2003; Sharma \& Yetton, 2003; Leonard, 2000, 2004). These authors highlighted a set of reasons why physicians failed on IS/IT acceptance, namely: (a) On an adequate base support; (b) Absence of user-friendly interfaces; (c) Difficulties on the information collection process; (d) In adequate training plan; (e) Lack of leadership in IS/IT that was respected by physicians; (f) Organization control default over the clinical practices.

The IS/IT interventions are perceived as an interference in the traditional physician role. The resistance is higher when the IS/IT interventions does not generate additional value for physicians' practices (Leonard \& Winkelman, 2002). There are also reported innovative approaches concerning the improvement of the IS/IT in healthcare adoption (Burke, 2002; Cranfield et al., 2015; Cresswell et al., 2013). The research effort developed the academy focused mainly on the identification of the elements with the hope those will effective ensure the IS/IT implementations, mainly in: (a) Identifying information insufficiencies and difficulties that are healthcare exclusively; (b) Identifying areas where the IS/IT implementations can make most difference; (c) Building systems that support shared objectives; (d) Designing and developing scalable tools, provider-patient interfaces and Internet applications; (e) Investing in existing resources.

Since success can be judged in many dimensions, such as; effectiveness, efficiency, organizational attitudes and commitment, employee satisfaction, and patient satisfaction, existing CSF lists could be problematic, making the situation very complex and offer a more simplified solution than what is needed in practice (Berg, 2001). Leonard (2004) identifies a set of CSFs for new technological adoption, such as: (a) Resistance to change; (b) Industry experience in using technology; (c) Training before and during the transition; (e) Buy-in or contribution from stakeholder groups; (f) Level of effective reporting on outcome measures during and after implementation; (g) Level of effectiveness in dealing with the implementation.

According to Medlin et al. (2014) the implementation of success cost-effective interventions in healthcare are mainly due: (a) A strong leadership; (b) Affective management; (c) Realistic financing; (d) A constantly improvements on strategy; (e) Processes by incorporating new research findings and technical innovation. Robinson (2007) highlighted factors such as: (a) The appropriate leadership; (b) Good communication; (c) Detailed roadmap of implementation; (d) Setting measurable goals; (e) Specific attention to the preparation of human resources in terms of motivation and training. Tempfer 
and Nowak (2011) addressed the organizational development in healthcare and identified the following success factors: (a) Adequate financing; (b) Partnerships; (c) Advanced project logistics; (d) Small scale projects; (e) Adequate internal and external communication.

Reyes-Alcázar et al. (2012) noted the CSFs that need to be considered for the health sector are the following: (a) A patient-centered approach: needs and expectations of end-users (Mead \& Bower, 2000); (b) Leadership: the importance on improving the quality of healthcare (West et al., 2004); (c) Team work: a multidisciplinary process focused on a healthcare team that shares common goals (Mickan, 2005); (d) Autonomy and responsibility: greater autonomy among health professionals (Harrison \& Dowswell, 2002); (e) An integrated view of healthcare; the quality of patient care as perceived by end-users is a key element (Torres-Olivera, 2003); (f) Professional skills: promoting skills encourages professional development (Reyes-Alcázar et al., 2012); (g) Results focused: the measurement and evaluation of clinical performance, hospital management and end-user satisfaction; (h) Internal and external audits: continuous quality improvement cicle (Patton, 2008; Hyrkäs \& Lehti, 2003; Le Brasseur et al., 2002).

CSFs have been criticized as offering over-simplified solutions that are difficult to realize in practice, since many contextual circumstances also influence the outcome (Berg, M. (2001; Wagner et al., 2006).

\section{CONCLUSION}

The ongoing health developments are driven mainly by demographic changes, which include increasing population aging, chronic diseases, cultural changes, advances in science and technology, widespread access to digital networks, and awareness of the need to improve quality and safety in the provision of health care. Today's technology plays a significant role, permitting the storage and rapid retrieval of patient records and other important information. At the same time, patients expect that their sensitive personal information to be handled appropriately, to ensure accuracy and confidentiality. Healthcare organizations become more and more challenged on how to assure a fair return from investments in IS/IT.

IS/IT has been referred to, as a key instrument in healthcare delivery and public health. IS/IT have great potential to improve healthcare by enhancing access to health information and making health services more efficient. They can also contribute to improving the quality of services and reducing their cost. A patient-centered information system can track individual health problems and treatment over time, giving insights about optimal diagnosis and treatment of the individual, as well as improving the delivery of services. The main goal of IS/IT is to manage information from all healthcare-related activities, including planning, monitoring, coordination, and decision making. The real-time access, exchange and receipt of clinical data provided by the system have improved clinical documentation, reduced the duplication of care services, and supported better decision making related to patient care. IS/IT are designed to support clinicians in accessing and working with a variety of patient information and promoting healthcare quality information sharing. Proper training is a major determinant for success in the adoption of IS/IT by health professionals, and it has a great influence on the integration of technologies in clinical practice. Authors identify organizational culture as exerting a positive influence on the development of superior project management practices. Critical success factors are specific elements of the organization of the internal and external environment, which is necessary to ensure goal attainment and the success of a project. As previously mentioned, the IS/IT investments in healthcare brings many benefits to day-by-day of the organizations. As also previously referred, these implementations have a large impact on all areas of the health organizations, professional staff, managers, politicians and public. Some of the following incidents remain current and actions are required for their minimization and resolution. These profound changes implicate important ethical challenges. Observations of IS/IT implementations have shown that a change in 
technology alters roles, strategies, and paths to failure, highlighting that the recognition of these new trends recommends the examination of the new technologies for avoiding threats to safety and redesigning them to prevent undesirable accidents. The study of the success or failure of these initiatives has become vitally important for the performance of these organizations. 


\section{REFERENCES}

Abouzhara, M. (2011). Causes of failure in Healthcare IT projects. Proceedings of the 3th International Conference on Advance Management Science, IPEDR, 19, IACSIT. Available at: http://ipedr.com/vol19/9ICAMS2011-A00018.pdf

Al-Ahmad, A., Al-Fagih, K., Khanfar, K., Alsamara, K., Abuleil, S., \& Abu-Salem, H. (2009). A taxonomy of an IT project failure: Root causes. International Management Review, 5(1), 93-104.

Anderson, J. G. (1997). Clearing the way for physicians' use of clinical information systems. Communications of the ACM, 40(8), 83-90. doi:10.1145/257874.257895

Anderson, J. G., \& Aydin, C. E. (1994). Overview: Theoretical perspectives and methodologies for the evaluation of health care information systems. In J. G. Anderson, C. E. Aydin, \& S. J. Jay (Eds.), Evaluating health care information systems: Methods and applications (pp. 5-29). Thousand Oaks, CA: Sage Publications, Inc.

Andreassen, H. K., Bujnowska-Fedak, M. M., Chronaki, C. E., Duritru, R. C., Pudele, I., Santana, S., \& Wynn, R. et al. (2007). European citizens' use of E-health services: A study of seven countries. BMC Public Health, 7(53), 1-7. PMID:17425798

Aral, S., Brynjolfsson, E., \& Van Alstyne, M. (2007) Information, Technology and Information Worker Productivity Task Level Evidence. Information System Research. Available at: SSRN: https://ssrn.com/ abstract $=942310$

Barrett, M. J., Holmes, B. J., \& McAulay, S. E. (2003). Electronic Medical Records: A Buyer's Guide for Small Physician Practices. Oakland, CA: California HealthCare Foundation.

Bates, D., Cohen, M., Leape, L., Overhage, J., Shabot, M., \& Sheridan, T. (2001). Reducing the frequency of errors in medicine using information technology. Journal of the American Medical Informatics Association, 8(4), 299-308. doi:10.1136/jamia.2001.0080299 PMID:11418536

Bates, D., \& Gawande, A. A. (2002). Error in medicine: What have we learned? Annals of Internal Medicine, 132(9), 763-767. doi:10.7326/0003-4819-132-9-200005020-00025 PMID:10787381

Beccalli, E. (2007). Does IT investment improve bank performance? Evidence from Europe. Journal of Banking \& Finance, 31(7), 2205-2230. doi:10.1016/j.jbankfin.2006.10.022

Berg, M. (2001). Implementing information systems in health care organisations: Myths and challenges. International Journal of Medical Informatics, 64(2-3), 143-156. doi:10.1016/S1386-5056(01)00200-3 PMID:11734382

Berghout, E., Nijland, M., \& Grant, K. (2005). Seven ways to get your favoured IT project accepted-politics in IT evaluation. The Electronic Journal of Information System Evaluation, 8(1), 31-40.

Bose, R. (2003). Knowledge management-enabled health care management: Capabilities, infrastructure, and decision-making. Expert Systems with Applications, 24(1), 59-71. doi:10.1016/S0957-4174(02)00083-0

Bradley, G. (2006). Benefit Realization Management: A Practical Guide for Achieving Benefits through Change. Hants, UK: Gower Publishing.

Brailer, D. J., \& Terasawa, E. L. (2003). Use and Adoption of Computer-Based Patient Records. Oakland, CA: California HealthCare Foundation.

Brandrud, A. S., Schreiner, A., Hjortdahl, P., Helljesen, G. S., Nyen, B., \& Nelson, E. C. (2011). Three Success Factors for Continual Improvement in Healthcare: An Analysis of the Reports of Improvement Team Members. BMJ Quality \& Safety, 20(3), 251-259. doi:10.1136/bmjqs.2009.038604 PMID:21209149

Brynjolfsson, E. (1993). The Productivity Paradox of Information Technology. Communications of the ACM, 36(12), 67-77. doi:10.1145/163298.163309

Bukachi, F., \& Pakenham-Walsh, N. (2007). Information technology for health in developing countries. Chest Journal, 132(5), 1624-1630. doi:10.1378/chest.07-1760 PMID:17998362

Burke, D., Wang, B., Wan, T., \& Diana, N. (2002). Exploring Hospitals' Adoption of Information Technology. Journal of Medical Systems, 26(4), 349-355. doi:10.1023/A:1015872805768 PMID:12118818 
Byrne, C. M., Mercincavage, L. M., Pan, E. C., Vincent, A. G., Johnston, D. S., \& Middleton, B. (2010). The value from investments in health information technology at the U.S. Department of Veterans Affairs. Health Affairs, 29(4), 629-638. doi:10.1377/hlthaff.2010.0119 PMID:20368592

Chau, P. Y., \& Hu, P. (2002). Investigating healthcare professionals' decisions to accept telemedicine technology: An empirical test of competing theories. Information \& Management, 39(4), 297-311. doi:10.1016/S03787206(01)00098-2

Chaudhry, B., Wang, J., Wu, S., Maglione, M., Mojica, W., Roth, E., \& Shekelle, P. G. et al. (2006). Systematic Review: Impact of Health Information Technology on Quality, Efficiency, and Costs of Medical Care. Annals of Internal Medicine, 144(10), 742-752. doi:10.7326/0003-4819-144-10-200605160-00125 PMID:16702590

Chovil, N. (2010). One small step at a time: Implementing continuous quality improvement in child and youth health services. Child and Youth Services, 31(1), 21-34. doi:10.1080/01459350903505561

Collste, G. (2002). The Internet doctor and medical ethics Ethical implications of the introduction of the Internet into medical encounters. Medicine, Health Care, and Philosophy, 5(2), 121-125. doi:10.1023/A:1016083021422 PMID:12168987

Cranfield, S., Hendy, J., Reeves, B., Hutchings, A., Collin, S., \& Fulop, N. (2015). Investigating healthcare IT innovations: A "conceptual blending" approach. Journal of Health Organization and Management, 29(7), 1131-1148. doi:10.1108/JHOM-08-2015-0121 PMID:26556172

Cresswell, K., Bates, D., \& Sheikh, A. (2013). Ten key considerations for the successful implementation and adoption of large-scale health information technology. Journal of the American Medical Informatics Association, 20(e1), e9-e13. doi:10.1136/amiajnl-2013-001684 PMID:23599226

Dawson, A., \& Verweij, M. (Eds.). (2007). Ethics, Prevention, and Public Health. Oxford University Press.

Dedrick, J., Gurbaxani, V., \& Kraemer, K. L. (2003). Information technology and economic performance: A critical review of the empirical evidence. ACM Computing Surveys, 35(1), 1-28. doi:10.1145/641865.641866

Dehning, B., Richardson, V. J., Urbaczewski, A., \& Wells, J. D. (2004). Re-examining the Value Relevance of Ecommerce Initiatives. Journal of Management Information Systems, 21(1), 57-84. doi:10.1080/07421222.2 004.11045788

Dehning, B., Richardson, V. J., \& Zmud, R. W. (2003). The Value Relevance of Announcements of Transformational Information Technology Investments. Management Information Systems Quarterly, 27(4), 637-656. doi:10.2307/30036551

Demiris, G., \& Kneale, L. (2015). Informatics Systems and Tools to Facilitate Patient-centered Care Coordination. IMIA Yearbook of Medical Informatics, 10(1), 15-21. PMID:26293847

Devaraj, S., \& Kohli, R. (2003). Performance Impacts of Information Technology: Is Actual Usage the Missing Link? Management Science, 49(3), 273-289. doi:10.1287/mnsc.49.3.273.12736

Dibb, S. (2001). Customer Relationship Management and Barriers to the One Segment. Journal of Financial Services Marketing, 6(1), 10-23. doi:10.1057/palgrave.fsm.4770037

Dick, R. S., Steen, E. B., \& Detmer, D. E. (Eds.). (1997). The Computer-Based Patient Record: An Essential Technology for Health Care (revised edition). Washington, DC: Committee on Improving the Patient Record, National Academy of Sciences.

Dong, L., Neufeld, D., \& Higgins, C. (2009). Top management support of enterprise systems implementations. Journal of Information Technology, 24(1), 55-80. doi:10.1057/jit.2008.21

Dos Santos, B. L., Peffers, K. G., \& Mauer, D. C. (1993). The Impact of Information Technology Investment Announcements on the Market Value of the Firm. Information Systems Research, 4(1), 1-23. doi:10.1287/ isre.4.1.1

Drury, P. (2005). The eHealth agenda for developing countries. World Hospitals and Health Services, 41, 38-40. PMID:16512063 
EC. (2006). ICT for Health and i2010: Transforming the European healthcare landscape -Towards a strategy for ICT for Health. Information Society \& Media Directorate General, European Commission. Available at: https:// ec.europa.eu/digital-single-market/en/news/ict-health-and-i2010-transforming-european-healthcare-landscape

Elder, L., \& Clarke, M. (2007). Past, present and future: Experiences and lessons from telehealth projects. Open Medicine: a Peer-Reviewed, Independent, Open-Access Journal, 1(3), 166-170. PMID:21673948

Gagnon, M. P., Ghandour, E. K., Talla, P. K., Simonyan, D., Godin, G., Labrecque, M., \& Rousseau, M. et al. (2014). Electronic health record acceptance by physicians: Testing an integrated theoretical model. Journal of Biomedical Informatics, 48, 17-27. doi:10.1016/j.jbi.2013.10.010 PMID:24184678

Gauld, R. (2007). Public sector information systems project failures: Lessons from a New Zealand hospital organization. Government Information Quarterly, 24(1), 102-114. doi:10.1016/j.giq.2006.02.010

Geissbuhler, A., Lovis, C., Lamb, A., \& Spahni, S. (2001). Experience with an XML/HTTP-based federative approach to develop a hospital-wide clinical information system. Studies in Health Technology and Informatics, 84(1), 735-739. PMID:11604834

Ghazvini, A., \& Shukur, Z. (2013). Security challenges and success factors of electronic healthcare system. Procedia Technology, 11, 212-219. doi:10.1016/j.protcy.2013.12.183

Gheorghiu, F. (2006). Why companies fail on the way to implementing project management methodology. Project Management Today, 8(10), 1-7.

Goddard, B. L. (2000). Termination of a contract to implement an enterprise electronic medical record system. Journal of the American Informatics Association, 7(6), 564-568. doi:10.1136/jamia.2000.0070564 PMID: 11062230

Gomes, J. (2018). Organisational Maturity and Information Systems and Technology Projects in Healthcare: The Mediation of Project Management (PhD dissertation). ISEG, Universidade de Lisboa.

Gomes, J., \& Romão, M. (2016). Improving the success of IS/IT projects in Healthcare: Benefits and Project Management approaches. In Advances in Intelligent Systems and Computing (vol. 444, pp. 547-556). New Advances in Information Systems and Technologies, Springer International Publishing AG, Part of Springer Science+Business Media.

Gomes, J., \& Romão, M. (2017). Aligning Information Systems and Technology with Benefit Management and Balanced Scorecard. In S. De Haes \& W. Van Grembergen (Eds.), Strategic IT Governance and Alignment in Business Settings (pp. 112-131). Hershey, PA: IGI Global. doi:10.4018/978-1-5225-0861-8.ch005

Gomes, J., Romão, M., \& Caldeira, M. (2013). The Benefits Management and Balanced Scorecard Strategy Map: How They Match. International Journal of IT/Business Alignment and Governance, 4(1), 44-54. doi:10.4018/ jitbag.2013010104

Grimson, J., Grimson, W., \& Hasselbring, W. (2000). The system integration challenge in health care. Communications of the ACM, 43(6), 49-55. doi:10.1145/336460.336474

Grossmann, C., Powers, B., \& McGinnis, J. M. (2011). Digital Infrastructure for The Learning Health System: The Foundation for Continuous Improvement in Health and Health Care. Washington, DC: Institute of Medicine, The National Academies Press.

Han, K., Chang, Y. B., \& Hahn, J. (2011). Information Technology Spillover and Productivity: The Role of Information Technology Intensity and Competition. Journal of Management Information Systems, 28(1), 115-145. doi:10.2753/MIS0742-1222280105

Harrison, S., \& Dowswell, G. (2002). Autonomy and bureaucratic accountability in primary care: What English general practitioners say. Sociology of Health \& Illness, 24(2), 208-226. doi:10.1111/1467-9566.00291

Häyrinen, K., Saranto, K., \& Nykänen, P. (2008). Definition, Structure, Content, Use and Impacts of Electronic Health Records: A Review of the Research Literature. International Journal of Medical Informatics, 77(5), 291-304. doi:10.1016/j.ijmedinf.2007.09.001 PMID:17951106

Heeks, R. B. (2002). Information Systems and Developing Countries: Failure, Success, and Local Improvisations. The Information Society, 18(2), 101-112. doi:10.1080/01972240290075039 
Heeks, R. B. (2008). Success and failure rates of e-Government in developing/transitional countries: Overview. Building Digital Opportunities Programme, Information Exchange, University of Manchester's Institute for Development Policy and Management.

Heeks, R. B., \& Davies, A. (1999). Different approaches to information age. In R. B. Heeks (Ed.), Reinventing Government in the Information Age. London: Routledge.

Hitt, L. M., \& Brinjolfsson, E. (1996). Productivity, business profitability, and consumer surplus: Three different measures of information technology value. Management Information Systems Quarterly, 20(2), 121-142. doi:10.2307/249475

Hung, S. Y., Chen, C., \& Wang, K. H. (2014). Critical success factors for the implementation of integrated healthcare information systems projects: An organizational fit perspective. Communications of the Association for Information Systems, 34(1), 775-796.

Hyrkäs, K., \& Lehti, K. (2003). Continuous quality improvement through team supervision supported by continuous self-monitoring of work and systematic patient feedback. Journal of Nursing Management, 11(3), 208-226. doi:10.1046/j.1365-2834.2003.00369.x PMID:12694365

Im, K. S., Dow, K. E., \& Grover, V. (2001). A reexamination of IT investment and the market value of the firm - An event study methodology. Information Systems Research, 12(1), 103-117. doi:10.1287/isre.12.1.103.9718

Jensen, T. B. (2013). Design Principles for Achieving Integrated Healthcare Information Systems. Health Informatics Journal, 19(1), 29-45. doi:10.1177/1460458212448890 PMID:23486824

Kaplan, B., \& Harris-Salamone, K. (2009). Health IT success and failure: Recommendations from literature and an AMIA workshop. Journal of the American Medical Informatics Association, 16(3), 291-299. doi:10.1197/ jamia.M2997 PMID:19261935

Katz, J. E., \& Rice, R. E. (2002). Social Consequences of Internet Use: access, involvement, and interaction. Cambridge, MA: MIT Press.

Kazanjian, A., \& Green, C. (2002). Beyond effectiveness: The evaluation of information systems using a comprehensive health technology assessment framework. Computers in Biology and Medicine, 32(3), 165-177. doi:10.1016/S0010-4825(02)00013-6 PMID:11922933

Kim, J. K., Xiang, J. Y., \& Lee, S. (2009). The impact of IT investment on firm performance in China: An empirical investigation of the Chinese electronics industry. Technological Forecasting and Social Change, 76(5), 678-687. doi:10.1016/j.techfore.2008.03.008

Kohli, R., \& Grover, V. (2008). Business value of IT: An essay on expanding research directions to keep up with the times. Journal of the Association for Information Systems, 9(1), 23-39. doi:10.17705/1jais.00147

Koumaditis, K., Themistocleous, M., \& Rupino da Cunha, P. (2013). SOA implementation critical success factors in healthcare. Journal of Enterprise Information Management, 26(4), 343-362. doi:10.1108/JEIM-06-2012-0036

Kumar, S., \& Preetha, G. S. (2012). Health Promotion: An Effective Tool for Global Health. Indian Journal of Community Medicine, 37(1), 5-12.

Le Brasseur, R., Whissell, R., \& Ojha, A. (2002). Organizational learning, transformational leardship, and implementation of continuous quality improvement in Canadian Hospitals. Australian Journal of Management, 27(2), 141-162. doi:10.1177/031289620202700203

Lee, S., Xiang, J. Y., \& Kim, J. K. (2011). Information Technology and Productivity: Empirical Evidence from the Chinese Electronics Industry. Information \& Management, 48(2/3), 79-87. doi:10.1016/j.im.2011.01.003

Leonard, K. J. (2000). Information Systems for Healthcare: Why we haven't had more success: The Top 15 Reasons. Healthcare Management Forum, 13(3), 45-51. doi:10.1016/S0840-4704(10)60776-4 PMID:15892319

Leonard, K. J. (2004). Critical Success Factors Relating to Healthcare's Adoption of New Technology: A Guide to Increasing the Likelihood of Successful Implementation. ElectronicHealthcare, 2(4), 72-81.

Leonard, K. J., \& Winkelman, W. (2002). Developing Electronic Patient Records: Employing Interactive Methods to Ensure Patient Involvement. Proceedings of the Proceedings of the 28th Meeting of the European Working Group on Operational Research Applied to Health Services (ORAHS), 241-255. 
Liang, H., Saraf, N., Hu, Q., \& Xue, Y. (2007). Assimilation of enterprise systems: The effect of institutional pressures and the mediating role of top management. Management Information Systems Quarterly, 31(1), 59-87. doi: $10.2307 / 25148781$

Lin, W. T., \& Shao, B. B. (2006). Assessing the input effect on productive efficiency in production systems the value of information technology capital. International Journal of Production Research, 44(9), 1799-1819. doi:10.1080/00207540500353889

Liu, S., Zhang, J., Keil, M., \& Chen, T. (2010). Comparing senior executive and project manager perceptions of IT project risk: A Chinese Delphi study. Information Systems Journal, 20(4), 319-355. doi:10.1111/j.13652575.2009.00333.x

Lorenzi, N. M., \& Riley, R. (2003). Organizational issues = change. International Journal of Medical Informatics, 69(2-3), 97-203. doi:10.1016/S1386-5056(02)00105-3 PMID:12810124

Lorenzi, N. M., \& Riley, R. T. (2000). Managing change: An overview. Journal of the American Medical Informatics Association, 7(2), 116-124. doi:10.1136/jamia.2000.0070116 PMID:10730594

Low, C., \& Chen, Y. (2012). Criteria for the evaluation of a cloud- based hospital information system outsourcing provider. Journal of Medical Systems, 36(6), 3543-3553. doi:10.1007/s10916-012-9829-z PMID:22366976

Lucas, H. (2008). Information and communications technology for future health systems in developing countries. Social Medicine (Social Medicine Publication Group), 66(10), 2122-2132. PMID:18343005

Lueg, R., \& Lu, S. (2012). Improving efficiency in budgeting: An interventionist approach to spreadsheet accuracy testing. Problems and Perspectives in Management, 10, 32-41.

Lueg, R., \& Lu, S. (2013). How to improve efficiency in budgeting: The case of business intelligence in SMEs. European Journal of Management, 13(2), 109-120. doi:10.18374/EJM-13-2.13

Lymberis, A., \& Dittmar, A. (2007). Advanced Wearable Health Systems and Applications: Research and Development Efforts in the European Union. IEEE Engineering in Medicine and Biology Magazine, 26(3), 29-33. doi:10.1109/MEMB.2007.364926 PMID:17549917

Mäenpää, T., Suominen, T., Asikainen, P., Maass, M., \& Rostila, I. (2009). The outcomes of regional healthcare information systems in health care: A review of the research literature. International Journal of Medical Informatics, 78(11), 757-771. doi:10.1016/j.jimedinf.2009.07.001 PMID:19656719

Mahmood, M. A., \& Mann, G. J. (2005). Information technology investments and organizational productivity and performance: An empirical investigation. Journal of Organizational Computing and Electronic Commerce, 15(3), 185-202. doi:10.1207/s15327744joce1503_1

Markus, M. L., Axline, S., Petrie, D., \& Tanis, C. (2000). Learning from adopters' experiences with ERP: Problems encountered, and success achieved. Journal of Information Technology, 14(4), 245-265. doi:10.1080/02683960010008944

Mead, N., \& Bower, P. (2000). Patient-centeredness: A conceptual framework and review of empirical literature. Social Science \& Medicine, 51(7), 1087-1110. doi:10.1016/S0277-9536(00)00098-8 PMID:11005395

Medlin, C., Chowdhury, M., Jamison, D., \& Measham, A. (2006). Improving the Health of Populations: Lessons of Experience. In Disease Control Priorities in Developing Countries (2nd ed.). Washington, DC: World Bank.

Mickan, S. (2005). Evaluating the effectiveness of health care teams. Australian Health Review, 29(2), 211-217. doi:10.1071/AH050211 PMID:15865572

Mithas, S., Tafti, A., Bardhan, T., \& Goh, J. M. (2012). Information Technology and Firm Profitability: Mechanisms and Empirical Evidence. Management Information Systems Quarterly, 36(1), 205-224. doi:10.2307/41410414

Munthe, C. (2008). The Goals of Public Health: An Integrated, Multidimensional Model. Public Health Ethics, 1(1), 39-52. doi:10.1093/phe/phn006

Murray, E., Lo, B., Pollack, L., Donelan, K., Catania, J., Lee, K., \& Turner, R. et al. (2003). The Impact of Health Information on the Internet on Health Care and the Physician-Patient Relationship: National U.S. Survey among 1.050 U.S. Physicians. Journal of Medical Internet Research, 5(3), e17. doi:10.2196/jmir.5.3.e17 PMID:14517108 
Nagi, E., Law, C., \& Wat, F. (2008). Examining the Critical Success Factors in the Adoption of Enterprise Resource Planning. Computers in Industry, 59(6), 548-564. doi:10.1016/j.compind.2007.12.001

Neirotti, P., \& Paolucci, E. (2007). Assessing the strategic value of Information Technology: An analysis on the insurance sector. Information \& Management, 44(6), 568-582. doi:10.1016/j.im.2007.05.005

Netlleton, S., Burrows, R., O’ Malley, L., \& Watt, I. (2011). Health e-types? Information Communication and Society, 7(4), 531-553. doi:10.1080/1369118042000305638

Pan, E., Johnston, D., Walker, J., Adler-Milstein, J., Bates, D. W., \& Middleton, B. (2005). The Value of Healthcare Information Exchange and Interoperability. Chicago: Health Information Management and Systems Society.

Patton, M. Q. (2008). Utilization-Focused Evaluation (4th ed.). Thousand Oaks, CA: Sage Publications.

Peslak, A. R. (2003). A firm level study of information technology productivity using financial and market-based measures. Journal of Computer Information Systems, 43(4), 72-80.

Poon, E. G., Blumenthal, T., Jaggi, M., Honour, M. N., Bates, D. W., \& Kaushal, R. (2004). Overcoming barriers to adopting and implementing computerized physician order entry in US hospitals. Health Affairs, 23(4), 184-190. doi:10.1377/hlthaff.23.4.184 PMID:15318579

Raghupathi, W., \& Tan, J. (1999). Strategic use of information technology in healthcare: A state-of-the-art. Topics in Health Information Management, 1(1), 1-15. PMID:10539419

Rai, A., Patnayakuni, R., \& Patnayakuni, N. (1997). Technology investment and business performance. Communications of the ACM, 40(7), 89-97.

Ramirez, R., Melville, N., \& Lawler, E. (2010). Information technology infrastructure, organizational process redesign, and business value: An empirical analysis. Decision Support Systems, 49(4), 417-429. doi:10.1016/j. dss.2010.05.003

Reyes-Alcázar, V., Torres-Olivera, A., Núñes-García, D., \& Almuedo-Paz, A. (2012). Critical Success Factors for Quality Assurance in Healthcare Organisations. In M. Savsar (Ed.), Quality Assurance Management. Academic Press. doi:10.5772/33081

Robinson, C. (2007). Clinician adoption of healthcare information technology. Canadian Nursing Informatics, 2(1), 4-21.

Roztocki, N., \& Weistroffer, H. R. (2008). Event Studies in Information Systems Research: A Review. Proceedings of the Americas Conference on Information Systems (AMCIS 2008). Available at: http://aisel. aisnet.org/amcis2008/248

Sabherwal, R., Jeyaraj, A., \& Chowa, C. (2006). Information System Success: Individual and Organizational Determinants. Management Science, 52(12), 1849-1864. doi:10.1287/mnsc.1060.0583

Santhanam, R., \& Hartono, E. (2003). Issues in linking information technology capability to firm performance. Management Information Systems Quarterly, 27(1), 125-153. doi:10.2307/30036521

Santos, C., Santos, V., Tavares, A., \& Varajão, J. (2014). Project Management Success in Health - The need of additional research in public health projects. Procedia Technology, 16, 1080-1085. doi:10.1016/j. protcy.2014.10.122

Schultz, J. (2006). Measuring Service Industry Performance: Some Basic Concepts. Performance Improvement, 45(4), 13-19. doi:10.1002/pfi.2006.4930450405

Sharma, R., \& Yetton, P. (2003). The contingent effects of management support and task interdependence on successful information systems implementation. Management Information Systems Quarterly, 27(4), 533-556. doi: $10.2307 / 30036548$

Shin, N. (2006). The impact of information technology on the financial performance of diversified firms. Decision Support Systems, 41(4), 698-707. doi:10.1016/j.dss.2004.10.003

Shortliffe, E. H., \& Barnett, G. O. (2014). Biomedical data: their acquisition, storage and use. In Biomedical informatics (pp. 39-66). London: Springer. doi:10.1007/978-1-4471-4474-8_2 
Smith, P. C., Mossialos, E., Papanicolas, I., \& Leatherman, S. (2009). Performance measurement for health system improvement: experiences, challenges and prospects. Cambridge, UK: Cambridge University Press.

Southon, F., Sauer, C., \& Dampney, C. (1999). Lessons from a failed information systems initiative: Issues for complex organisations. International Journal of Medical Informatics, 55(1), 33-46. doi:10.1016/S13865056(99)00018-0 PMID:10471239

Sumner, M. (1999). Critical Success Factors in Enterprise Wide Information Management Systems Projects. Proceedings of Americas Conference on Information Systems. doi:10.1145/299513.299722

Swierczek, F. W., \& Shrestha, P. K. (2003). Information technology and productivity: A comparison of Japanese and Asia-Pacific banks. The Journal of High Technology Management Research, 14(2), 269-288. doi:10.1016/ S1047-8310(03)00025-7

Tempfer, C., \& Nowak, P. (2011). Consumer participation and organizational development in health care: A systematic review. Wiener Klinische Wochenschrift, 123(13-14), 408-414. doi:10.1007/s00508-011-0008-x PMID:21739200

Terry, A. L., Thorpe, C. F., Giles, G., Brown, J. B., Harris, S. B., Reid, G. J., \& Stewart, M. et al. (2008). Implementing electronic health records: Key factors in primary care. Canadian Family Physician Medecin de Famille Canadien, 54(5), 730-736. PMID:18474707

Themistocleous, M., Mantzana, V., \& Morabito, V. (2009). Achieving Knowledge Management Integration through EAI: A Case Study from Healthcare Sector. International Journal of Technology Management, 47(1-3), 114-126. doi:10.1504/IJTM.2009.024117

Tierney, W. (2001). Improving clinical decisions and outcomes with information: A review. International Journal of Medical Informatics, 62(1), 1-9. doi:10.1016/S1386-5056(01)00127-7 PMID:11340002

Torres-Olivera, A. (2003). La gestión por procesos asistenciales integrales: Una estrategia necesaria. Atencion Primaria, 31(9), 561-563. doi:10.1016/S0212-6567(03)79216-6 PMID:12783744

Wagner, E., Scott, S., \& Galliers, R. (2006). The creation of 'best practice' software: Myth, reality and ethics. Information and Organization, 16(3), 251-275. doi:10.1016/j.infoandorg.2006.04.001

Ward, J., Taylor, P., \& Bond, P. (1996). Evaluation and realization of IS/IT benefits: An empirical study of current practice. European Journal of Information Systems, 4(4), 214-225. doi:10.1057/ejis.1996.3

Wears, R. L., \& Berg, M. (2005). Computer technology and clinical works: Still waiting for Godot. Journal of the American Medical Association, 293(10), 1261-1263. doi:10.1001/jama.293.10.1261 PMID:15755949

Weick, K. E., \& Sutcliffe, K. M. (2001). Managing the unexpected: Assuring high performance in an age of complexity. San Francisco, CA: Jossey-Bass.

West, B., Lyon, M., McBain, M., \& Gass, J. (2004). Evaluation of a clinical leadership initiative. Nursing Standard, 19(5), 33-41. doi:10.7748/ns.19.5.33.s61 PMID:15524254

West, L. A., \& Courtney, J. F. (1993). The Information Problems in Organisations - A Research Model for the Value of Information and Information Systems. Decision Sciences, 24(2), 229-251. doi:10.1111/j.1540-5915.1993. tb00473.x

Westbrook, J., Braithwaite, J., Iedema, R., \& Coiera, E. (2004). Evaluating the impact of information communication technologies on complex organizational systems: A multi-disciplinary multi-method framework. Studies in Health Technology and Informatics, 107, 1323-1327. PMID:15361029

WHO. (2005). Connecting for Health: Global Vision, Local Insight. Report for the World Summit on the Information Society. Geneva, Switzerland: World Health Organization. Available at: http://www.who.int/ehealth/ resources/wsis_report/en/

WHO. (2006). Building foundations for eHealth: Progress of Member States. Geneva, Switzerland: World Health Organization. Available at: http://www.who.int/goe/publications/build_foundations/en/

Wootton, R. (2009). The future use of telehealth in the developing world. In Telehealth in the Developing World. London: Royal Society of Medicine Press. 
Yasnoff, W. A., Humpheys, B. L., Overhage, J. M., Detmer, D. E., Brennan, P. F., Morris, R. W., \& Fanning, J. P. et al. (2004). A consensus action agenda for achieving the national health information infrastructure. Journal of the American Medical Informatics Association, 11(49), 332-338. doi:10.1197/jamia.M1616 PMID:15187075

Yeo, K. T. (2002). Critical failure factors in information system projects. International Journal of Project Management, 20(3), 241-246. doi:10.1016/S0263-7863(01)00075-8

Yusof, M. M., Kuljis, J., Papazafeiropoulou, A., \& Stergioulas, L. K. (2008). An evaluation framework for health information systems: Human, organization and technology-fit factors (HOT-fit). International Journal of Medical Informatics, 77(6), 386-398. doi:10.1016/j.jmedinf.2007.08.011 PMID:17964851

Zhang, M. J. (2005). Information systems, strategic flexibility and firm performance: An empirical investigation. Journal of Engineering and Technology Management, 22(3), 163-184. doi:10.1016/j.jengtecman.2005.06.003

Jorge Gomes is a researcher at ADVANCE, ISEG, School of Economics \& Management of the Universidade de Lisboa. He holds a PhD in Management from ISEG and a Masters in Management Sciences from ISCTE-IUL, He also have a post-graduation in Project Management from INDEG/ISCTE, and a degree in Geographic Engineering from the Faculty of Sciences of the Universidade de Lisboa. During the past 30 years, he has worked as an engineer, project manager, quality auditor and consultant. In the present he teaches in the executive formation of IDEFE, ISEG. His research interests include Benefits Management, Project Management, Project Success, Maturity Models, IS/IT Investments, IS/IT in Healthcare and IS/IT Management.

Mário Romão is an Associate Professor of Information Systems and Operations Management, at ISEG - University of Lisbon - Portugal. He holds a PhD in Management Sciences from ISCTE (Portugal) and by Cranfield University (UK); a Master in Telecommunications and Computer Science by Instituto Superior Técnico (IST - University of Lisbon); a post-graduation in Project Management - Best Practitioner Program, by ISLA; a degree in Electrotechnical Engineering, by IST; and a PMP - Project Management Professional Certification, by PMI - Project Management International. He has held positions of Board member and executive Director in organizations from private sectors (e.g. Telco, Software). 